\title{
Severity of Newly Emerging Pomegranate Wilt caused by Ceratocystis fimbriata Ellis and Halst. in North Karnataka, India
}

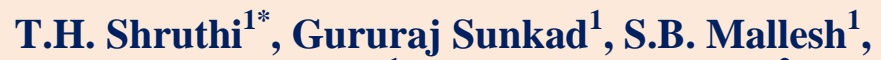 \\ S.T. Yenjerappa ${ }^{1}$ and Mahadevswamy ${ }^{2}$ \\ ${ }^{1}$ Department of Plant Pathology, ${ }^{2}$ Department of Agril. Microbiology, College of Agriculture, \\ University of Agricultural Sciences, Raichur-584104, Karnataka, India \\ *Corresponding author
}

\begin{tabular}{|l|}
\hline Key w o r d s \\
Pomegranate, Wilt, \\
Survey, \\
Ceratocystis \\
fimbriata, Disease \\
incidence
\end{tabular}

Keywords

Pomegranate, Wilt,

Survey,

Ceratocystis

fimbriata, Disease incidence

\section{Article Info}

Accepted:

22 July 2019

10 August 2019

\section{A B S T R A C T}

Pomegranate (Punica granatum L.) is an ancient fruit, belonging to the family Punicaceae. It is one of the vital cash crops of our country and it is commonly called as fruit of paradise. The successful cultivation of pomegranate is often suffers from different diseases. Among these wilt of pomegranate caused by Ceratocystis fimbriata Ellis \& Halst. is a major threat for its cultivation and is second most important and destructive disease of pomegranate cultivation causing extensive yield loss. A roving survey was carried out to assess severity of wilt of pomegranate in major pomegranate growing regions of North Karnataka during kharif 2016. The results revealed that the wilt caused by C. fimbriata was observed in all the districts surveyed and Babaleswar village recorded highest incidence of wilt $(42.10 \%)$ followed by Hittinahalli village of Vijayapur taluk $(38.05 \%)$ and least incidence of wilt was observed in Kudligi village (5.20\%) of Kudligi Taluk. Among the taluks surveyed, disease incidence varied from 5.83 to 38.13 per cent and highest mean disease incidence was noticed in Vijayapur taluk of 38.13 per cent, followed by Indi with 33.10 per cent and least mean disease incidence was observed in the Kudligi taluk of 5.83 per cent. Among districts, the highest disease incidence was recorded in Vijayapur district (35.61\%) followed by Bagalkot (32.91\%) and the least was in Ballari $(8.18 \%)$.

\section{Introduction}

Pomegranate (Punica granatum L.) is an ancient fruit, belongs to the subclass Rosidae, order Myrtales and smallest botanical family Punicaceae. Pomegranate is native to Iran (Stover and Mercure, 2007) and it is also thought to be a native in Turkey (Ercisli et al., 2007). Area under pomegranate is increasing worldwide because of its hardy nature, wider adaptability and drought tolerance, higher yield levels with excellent keeping quality and remunerative prices in domestic as well as export market. It is one of the most adaptable subtropical minor fruit and its cultivation is increasing rapidly.

In India, it is regarded as a "vital cash crop" and the major growing states are Maharashtra, Karnataka Andhra Pradesh, Telangana and 
followed by Gujarat. As per recent estimates for the year 2014-15, (http://nhb.gov.in) total area under pomegranate in India is 1.80 lakh ha. with total production of about 17.89 lakh tonnes in India. The fruits of pomegranate are known to possess pharmaceutical and therapeutic properties.

Several agents such as Ceratocystis, Fusarium and Rhizoctonia are known to cause wilt in pomegranate, but Ceratocystis fimbriata is the major cause of pomegranate found associated in 77 per cent of wilt samples collected from different locations of Maharashtra and Karnataka (Sharma, 2009; Sharma, et al., 2010). A survey of 44 locations in Maharashtra in India from 1995 to 1998 showed 7.5 per cent crop losses amounting to Rs. $\quad 30$ lakhs (Somasekhara, 1999). Somasekhara and Wali (2000) reported 12.29 per cent mean incidence ranging from 1.62 to 63.50 per cent in Maharashtra and Karnataka; monetary losses mounted to Rs. 67.45 lakhs during 1996-97 and Rs. 26.9 lakhs during 1999-2000. Reports suggest that 45 per cent of crop is severely affected by wilt pathogen and day by day its severity is increasing many folds.

The systematic work on important aspects of the pomegranate wilt and its pathogen is limited. Realizing the potentiality of wilt causing huge economic losses, it was thought necessary to initiate systematic studies on different aspects of the disease as well as management of pathogen. It is necessary to conduct the survey of the disease, so that its distribution and extent of its spread can be understood and "hot spots" can be located.

\section{Materials and Methods}

A roving survey was conducted during the kharif 2016 seasons in the pomegranate growing areas of the five districts of northern region of Karnataka viz., Vijayapur, Bagalkot, Koppal, Raichur and Ballari to asses wilt disease incidence. Pomegranate growing orchards / fields were identified from the records available from previous studies. The field visits were undertaken during pruning, flowering and fruit formation stages of the crop. During survey, in each district important pomegranate growing talukas were selected, in each taluka five orchards were selected for disease incidence. Plants were diagnosed on the basis of typical symptoms like yellowing of single branch from top to bottom at early stages and later progression of disease resulting in complete wilting of plants.

Samples of infected stem and roots were collected from wilt affected pomegranate plants. During survey various parameters viz., variety and type of irrigation and soil etc. will be recorded. The per cent of disease incidence in each orchard was calculated by the following formula.

Disease Incidence $(\%)=$

Number of plants infected

Total number of plants
X 100

The surveyed villages (Orchards) were categorized as severe $(>40 \%)$, moderately severe (10.1-40\%) and mild (0 to 10\%) as per Sharma et al., (2010).

\section{Results and Discussion}

A roving survey was conducted in five districts of Northern Karnataka viz., Vijayapur, Bagalkot, Koppal, Raichur and Ballari. The survey results revealed that disease incidence was noticed in all regions of Northern Karnataka, wherever pomegranate orchard were established. During the survey the age of the crop, type of soil, variety grown and type of irrigation and other parameters were recorded. 
In pomegranate orchard, wilt was recorded in all the locations surveyed with range of 5.83 to 42.10 per cent. Maximum wilt incidence was observed in Vijayapur district $(38.05 \%)$ followed by Bagalkot (32.01\%), Koppal $(30.02 \%)$ and least incidence was in Ballari district $(8.18 \%)$. The data of per cent wilt incidence has been given in Table 1 .

Vijayapur district recorded the mean pomegranate wilt incidence of $35.61 \%$, maximum disease incidence was observed in Babaleswar (42.10\%) village of Vijayapur taluk followed by Hittinahalli (38.05\%) village of Vijayapur taluk and lowest incidence was noticed in Kannolli (34.20\%) village of Indi taluk.

The mean pomegranate wilt incidence of $32.91 \%$, maximum disease incidence was observed in Govindkopp (36.84\%) village of Bagalkot taluk followed by Mudhol rural $(36.10 \%)$ of Mudhol taluk and lowest incidence was noticed in Kaladgi $(26.89 \%)$ village of Bagalkot Taluk in Bagalkot district.

In Koppal district, the mean pomegranate wilt incidence was $30.60 \%$, maximum disease was noticed in Maladgati (38.57\%) village of Kustagi Taluk followed by Herebannigola (31.60\%) village of Kustagi Taluk and lowest disease incidence was noticed in Mandalmari $(21.90 \%)$ village of Yelburga Taluk.

In Raichur district, mean pomegranate wilt incidence of $12.09 \%$, maximum disease incidence were recorded in Yatgal $(24.30 \%)$ village of Deodurga Taluk followed by Ganjhalli (12.80\%) village of Raichur Taluk and lowest disease incidence were recorded in Karekal $(9.80 \%)$ village of Lingsugur Taluk. In Ballari, mean pomegranate wilt incidence was 8.18 per cent, maximum disease incidences were recorded in Bachigondanahalli (15.60\%) village of Hagaribomanahalli Taluk followed by
Khondanhalli (10.73\%) and lowest disease incidence was noticed in Kudligi village $(5.20 \%)$ of Kudligi Taluk (Table 1$)$.

Among the taluk surveyed, the disease incidence varied from 5.83 to $38.13 \%$ and the highest mean incidence of wilt $(38.13 \%)$ was recorded in Vijaypur taluk of Vijaypur district followed of Indi $(33.10 \%)$ taluk of Vijayapur district and Bagalkot (33.04\%) taluk of Bagalkot district. The least incidence of pomegranate wilt $(5.83 \%)$ was recorded in Kudligi taluk of Ballari district (Table 2).

Among the orchards, 4-5 year old orchards showed a higher disease incidence than the plants aged three years or less. Among Fifty five orchards, of which three orchards had wilt in severe form (> $40.0 \%$ incidence), thirty two orchards had wilt of moderate incidence (10.1 to $40 \%$ ) and twenty orchards had mild (up to $10 \%$ ) wilt incidence.

While collecting the information on disease incidence on above districts, type of variety grown, age of crop, soil type, type of irrigation and association of shot hole borer was also recorded. Most areas of Vijaypur and Bagalkot were covered with black soil and in association with higher incidence of shot hole borer which helps in spread of fungal pathogen. Hence, these areas were more prone to disease. Orchard of above five years old showed maximum disease incidence when compared to newly established orchards. The orchards established with infected planting materials showed early incidence of disease. Notably, Bhagwa and Kesar varieties were highly susceptible to $C$. fimbriata.

The first knowledge about distribution of disease and the extent of prevalence will guide to take up immediate control measures. In addition, the survey also gives indication about the occurrence and distribution of disease in a region. 
In the present study, a roving survey for wilt of pomegranate was carried out during 2016 in major pomegranate growing districts of Northern Karnataka. The data on survey revealed that, the wilt incidence varied from locality to locality, continuous cropping pattern and environmental condition. The overall mean incidence of pomegranate wilt was ranging from 5.83 to $42.10 \%$ on different cultivars such as Kesar, Ganesh and Bhagwa grown in Northern Karnataka. Similar studies were carried by Sharma et al., (2010) and reported the disease prevalence in all important cultivars.

The highest mean incidence of wilt $(38.13 \%)$ was recorded in Vijayapur taluk of Vijayapur district followed of Indi (33.10\%) taluk of Vijayapur district and Bagalkot (33.04\%) taluk of Bagalkot district. The least incidence of pomegranate wilt $(5.83 \%)$ was recorded in Kudligi taluk of Ballari district. Similar results were observed by earlier reports by Benagi et al., (2009), Jadhav and Sharma (2009), Somasekhara et al., (2009), indicated average incidence of 0.1- 33.3, 8.69 and 5.69 per cent respectively. In another study, Sonyal (2010) who conducted a roving survey for pomegranate wilt incidence in major pomegranate growing districts of Karnataka i.e., Bijapur, Bagalkot, Koppal, Gadag, Raichur and Ballari districts where in Bellary district recorded maximum disease incidence $(32.46 \%)$ followed by Koppal district $(32.13 \%)$, while lowest disease incidence was observed in Raichur district (16.70\%). A roving survey in different locations in districts of Bagalkot, Vijaypur, Koppal, Chitradurga, Mysuru, Raichur, Belgaum, Ballari and Chikkamagaluru was made. Highest disease was recorded in Vijaypur district with 23.22 per cent and lowest incidence in Belagavi and Bellary districts with 3.22 and 2.75 per cent, respectively (Aravind, 2016).
Among the orchards, 4 to 5 year old orchards showed a higher disease incidence than the plants aged three years or less. Among fifty five orchards, three orchards had wilt in severe form (> $40.0 \%$ incidence), thirty two orchards moderate form (10.1-40\%) and twenty orchards showed mild (up to 10\%) wilt incidence. Similar, results were observed by Huang et al., (2003) where in they detected in 17 of 50 plantings surveyed were diseased and the disease was more severe in older orchards than in younger plantings.

Similar studies were carried by Sharma et al., (2010) by intensive survey in Karnataka, Andhra Pradesh and Maharashtra in which wilt was prevalent in 47.57 per cent of orchards, of which only 5.82 per cent had severe wilt infections, 10.03 per cent moderate and 31.71 per cent mild wilt infections.

The higher disease incidence in Vijayapur, Bagalakot and Koppal districts in the present study may be attributed to the use of planting materials from infected orchards. The mono cropping also aggravated the disease situation and there is no resistant variety available. Practicing improper management practices by farmers in the initial period of the crop also made it difficult to manage the wilt. As per the present recommendation, on observing first symptoms of wilt in the orchards, soil drenching of infected plant along with 2 to 3 healthy plants on all the four sides with fungicides, repeat the drenching 3 to 4 times at 15 to 20 days interval has to be followed for effective management of disease. But this is not happening in the farmer's fields because the cultivation of pomegranate is labour intensive and costly. Moreover, infected plants are not removed timely from field and are not burnt by farmers. Because of these reasons, pathogen survives in the field and causes the disease in higher proportions. 
Table.3 Incidence of wilt in major pomegranate growing districts of Northern Karnataka during 2016

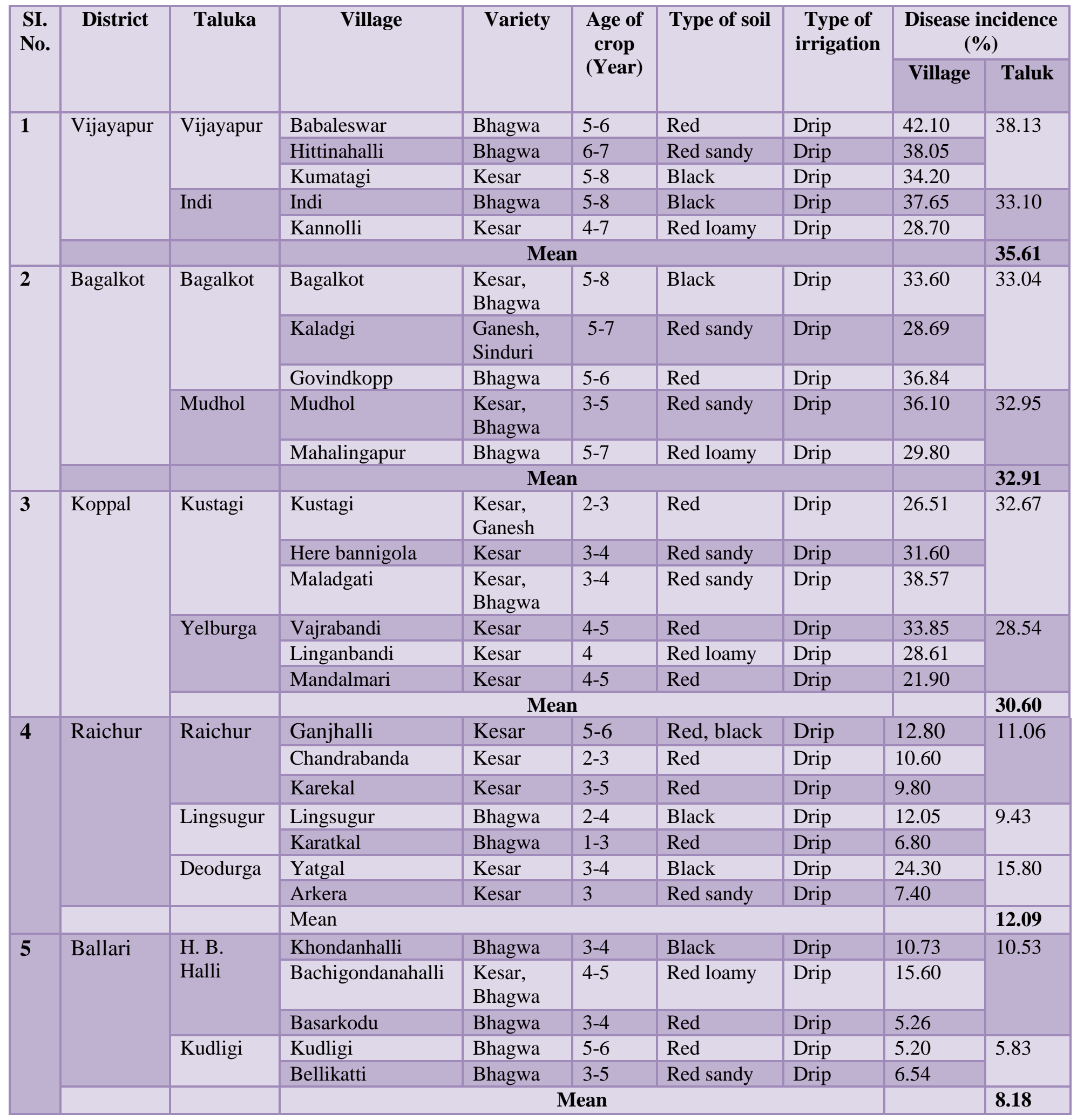


Table.2 District and talukwise pomegranate wilt incidence in parts of Northern Karnataka during 2016

\begin{tabular}{|c|c|c|c|c|}
\hline Sl. No. & District & Taluk & $\begin{array}{c}\text { Wilt incidence } \\
(\%)\end{array}$ & Mean \\
\hline \multirow[t]{2}{*}{1} & \multirow[t]{2}{*}{ Vijayapur } & Vijayapur & 38.13 & \multirow[b]{2}{*}{35.61} \\
\hline & & Indi & 33.10 & \\
\hline \multirow[t]{2}{*}{2} & \multirow[t]{2}{*}{ Bagalkot } & Bagalkot & 33.04 & \multirow[b]{2}{*}{32.91} \\
\hline & & Mudhol & 32.95 & \\
\hline \multirow[t]{2}{*}{3} & \multirow{2}{*}{ Koppal } & Kustagi & 32.67 & \multirow[b]{2}{*}{30.60} \\
\hline & & Yelburga & 28.54 & \\
\hline \multirow[t]{3}{*}{4} & \multirow{3}{*}{ Raichur } & Raichur & 11.06 & \multirow{3}{*}{12.09} \\
\hline & & Lingsugur & 9.43 & \\
\hline & & Deodurga & 15.80 & \\
\hline \multirow[t]{2}{*}{5} & \multirow[t]{2}{*}{ Ballari } & H. B. Halli & 10.53 & \multirow{3}{*}{$\begin{array}{r}8.18 \\
23.87\end{array}$} \\
\hline & & Kudligi & 5.83 & \\
\hline \multicolumn{4}{|c|}{ Overall mean incidence } & \\
\hline
\end{tabular}

The prophylactic management practices were also not followed by farmers to manage the fungal wilt disease of pomegranate in almost all the locations surveyed. The selection of pre infected cuttings with $C$. fimbriata led to the increased wilt incidence in the areas surveyed. Results were in agreement with Raja (2017) who conducted intensive fixed plot survey for wilt of pomegranate during Hastbahar 2014 and 2015 in major pomegranate growing districts of Karnataka viz., Vijayapur, Bagalkot, Koppal, Yadgir, Raichur, Ballari, Chitradurga, Tumakuru and Hassan. The highest pomegranate wilt $(30.62 \%)$ was recorded in Tumakur district followed by Bagalkot which recorded wilt incidence of 29.02 per cent and least wilt incidence of 14.81 per cent was recorded in Yadgir.

\section{References}

Aravind, 2016, Molecular characterization of Ceratocystis fimbriata and its associated defence functions in pomegranate during pathogenesis. M. Sc. (Agri.) Thesis, Univ. Agric. Sci., Bagalkot,
Karnataka.

Benagi, V. I., Ravikumar, M. R., Gowdar S. B. and Basavaraj, B. B., 2009, Survey on disease of pomegranate in northern Karnataka. Paper presented In: 2nd Inter. Symp. Pomegranate and minor including Mediterranean Fruits, University of Agricultural Sciences, Dharwad. June 23-27: 135.

Ercisli, S., Agar, G., Orhan, E., Yildirim, A and Hizarci, Y., 2007, Interspecific variability of RAPD and fatty acid composition of some pomegranate cultivars (Punica granatum L.) growing in Southern Anatolia Region in Turkey. Bio. Chem. Syst. Ecol., 35(1): 764-769.

Huang, Q., Zhu, Y. Y., Chen, H. R., Wang, Y. Y., Lie, Y. L., Lu, W. J. and, Ruan, X. Y., 2003, First report of pomegranate wilt caused by Ceratocystis fimbriata in Yunnan, China. Plant Dis., 87: 115.

Jadhav, V. T. and Sharma, K. K., 2009, Integrated management of disease in pomegranate. Paper Presented In: 2nd Inter. Symp. Pomegranate and minor including Mediterranean Fruits, Univ. Agric. Sci., Dharwad, June 23-27: 48- 
52.

Raja, 2017, Investigations on wilt of pomegranate caused by Ceratocystis fimbriata Ell. And Halst. in Karnataka. $P h$. D. Thesis, Univ. Agric. Sci., Raichur, Karnataka.

Sharma, K. K., 2009, Vascular wilt of pomegranate caused by Ceratocystis fimbriata Ellis and Halsted and its control. 5th International conference on Plant Pathology in the globalized Era, Nov,10-13, 2009 at IARI, New Delhi: 240.

Sharma, K. K., Sharma, J. and Jadhav, V. T., 2010, Etiology of pomegranate wilt and its management. In: Fruit, Vegetable, Cereal science and Biotechnology 4 (2), Global Science Books: 96-101.

Somasekhara, Y. M., 1999, New record of Ceratocystis fimbriata causing wilt of pomegranate in India. Plant Dis., 83: 406.
Somasekhara, Y. M. and Wali, S. Y., 2000, Survey of incidence of pomegranate (Punica granatum Linn.) wilt Ceratocystis fimbriata (Ell. \& Halst). Orissa J. Hort., 28: 84-89.

Somasekhara, Y. M., Wali, S. Y. and Shaik, M. K., 2009, Studies and the management of pomegranate (Punica granatum) wilt (Ceratocystis fimbriata, Latin American group). Second Inter. Symp. Pomegranate and Minor including Mediterranean Fruits, Univ. Agric. Sci., Dharwad: 132-133.

Sonyal, S., 2010, Studies on pomegranate wilt complex. M.Sc. Thesis, Plant Pathology, Univ. Agric. Sci., Dharwad, Karnataka (India): 86-93.

Stover, E. and Mercure, E.W., 2007, The pomegranate: A new look at the fruit of paradise. Hort. Sci., 42: 1088-1092.

http://nhb.gov.in

\section{How to cite this article:}

Shruthi, T.H., Gururaj Sunkad, S.B. Mallesh, S.T. Yenjerappa and Mahadevswamy. 2019. Severity of Newly Emerging Pomegranate Wilt caused by Ceratocystis fimbriata Ellis and Halst. in North Karnataka, India. Int.J.Curr.Microbiol.App.Sci. 8(08): 3032-3038. doi: https://doi.org/10.20546/ijcmas.2019.808.351 